\title{
Factors Influencing Student Engagement for Online Courses: A Confirmatory Factor Analysis
}

\author{
Shivani Inder \\ Chitkara Business School, Chitkara University, Punjab, India \\ ORCID: 0000-0002-4805-4118
}

Received: 1 May 2021

Accepted: 26 Sep 2021

\begin{abstract}
The purpose of the study is to develop and validate the scale for measuring the extent of student engagement for online courses. The study draws a battery of variables from literature on student engagement. The study proposes a 6 construct based scale with 26 items. A total of 1602 university students completed the responses for the scale. All participants had a minimum of two months of experience for online courses for inclusion in survey. Firstly, exploratory factor analysis on the initial scale has been carried out and then confirmatory factor analysis has been carried out for testing the validity and reliability of the scale. After establishing the validity of the scale, a scale with six main constructs has been confirmed. The results indicated that skills, emotional, participation and performance engagement along with value to students are the main drivers of student engagement for online courses. The scale can provide an insight to educators about the main factors that can lead to enhanced levels of engagement while delivering courses online and improve the learning experience for students.
\end{abstract}

Keywords: online courses, student engagement, confirmatory factor analysis, skills, participation

\section{INTRODUCTION}

During the recent times, universities and educational institutions across the globe have started giving importance to online platform for delivering courses. Though providing education through online mode comes with a number of benefits, yet engaging students for online courses can be challenging. Engaging students online is attracting a lot of attention. Student engagement, as an indicator of the quality of learning, is an important metric for assessing the success of any educational course. This places student engagement at the centre-stage of any online course. Online courses present a unique set of challenges when it comes to engaging students.

Tinto (2014) points the relevance of engagement by quoting 'engagement matters' (p.20). Nystrand and Gamoran (1991, p. 284) point that student engagement "depends on what teachers and students do together...neither can do it alone". Australasian Survey of Student Engagement Survey (2011) refers student engagement as "generating conditions that stimulate student involvement". Also, Burch et al. (2015) point that educator has both the desire and requirement to facilitate student learning.

Several researchers have attempted to examine the concept of student engagement. Student engagement has been treated as a proxy of quality teaching (Chalmers, 2008; Leach, 2016); predictor of learning (Burch et al., 2015); psychological investment towards learning and mastering the skills (Newmann et al., 1992); time and energy devoted to activities (Kuh, 2003); investment in terms of amount, type and intensity by students (Jennings \& Angelo, 2006); activity leading to critical thinking, grading and persistence (Kuh et al., 2007); involvement in educationally purposeful activities (Radloff \& Coates, 2010); incremental to critical 
thinking, reasoning, inquiry and intercultural effectiveness (Pascarella et al., 2010); byproduct of learning environment, time devoted towards work and effect on learning (Axelson \& Flick, 2011); and reduce student departure intentions (Jackling \& Natoli, 2011). It assists in connecting the students with learning (Kehrwald, 2008). Subsequently, Student engagement measures the efforts put in a course, the feelings involved in learning, connections made through the content, peer interaction, and gaining of skills related to participation, performance and emotions.

Student engagement is complex, multidimensional and contested construct, which has a number of supporting theories and plethora of reviews (Trowler \& Trowler, 2010). Several studies have identified student engagement across multiple dimensions: behavioral, psychological, socio-cultural and holistic perspective (Kahu, 2013); or behavioral, emotional and cognitive (Blumenfeld \& Paris, 2004).

Considering student engagement as a multidimensional phenomenon and construct, it is suggested as a black box (Hatch, 2012). Additionally, the complexity and incomplete discovery of the properties of construct can be highlighted (Astin, 1984; Bryson, 2014). Further, Bryson et al. (2010) suggest student engagement as actions taken by institution in 'engaging students' and the actions carried by students while learning in 'students engaging'. 'Engaging student' and 'students engaging' are indicated as process and outcome, respectively. Kahu and Nelson (2018) suggest the exploration of student engagement in different contexts.

The majority of prior studies have attempted to investigate student's satisfaction, or desire to use online learning while fewer studies have explored the factors leading to student engagement. The present study attempts to provide an insight on what engages students on online courses for Indian students who belong to urban and semi-urban areas. The study develops a scale for measuring the student engagement on online courses.

The rest of the study is structured as follows. Section Literature Review discusses the related literature. Section Methodology presents the data and methodology. Section Results provides the results and analysis, with discussion in Section Implications. Finally, Section Limitations and Scope for Future indicates the implications of the study.

\section{LITERATURE REVIEW}

The concept of student engagement can be traced back to 1930s where Student engagement is presented as time spent on work and effect on learning by Ralph Tyler (Axelson \& Flick, 2011). Earlier studies focused on 'Student Departure Theory' (Tinto, 1975), 'Quality of Student's efforts' (Pace, 1980), 'Student Involvement Theory' (Astin, 1984). These studies observe student engagement from the lens of student involvement, which in turn is considered as function of investment in physical and psychological energy, along with personal development. Student involvement theory underpins the theoretical foundation in management theory. Further, focusing on the employee engagement, Kahn (1990) argues that engaged employees devote more emotional, physical and cognitive resources while performing their roles in the organization. Handelsmann et al. (2005) identify engagement at the levels of skills, emotions, participation and performance as four major factors contributing toward student engagement. Further, Kahu (2013) stretches the dimensions of student engagement to behavioral, psychological and socio-cultural axis, by extending transition theory and cultural studies.

Transition theory brings in focus the challenge faced by students while transitioning from school environment to higher education institutes. Thus, transition flips the perspective presented in Student involvement theory. Kahu (2013) suggests student engagement happens at the interface provided the intersection point of student factors and institutional factors. He ropes in the behavioral, psychological and socio-cultural approach to student engagement via cultural dimensions. Educational researchers attempt to merge management theory with theoretical approach to merge management theory with theoretical approach to present dimensions to student engagement. Burch et al. (2015) modify the Rich et al.'s (2010) employee engagement scale and present four main components of student engagement to "emotional engagement, physical engagement, cognitive engagement in class and cognitive engagement out of class". Dixson (2015) 


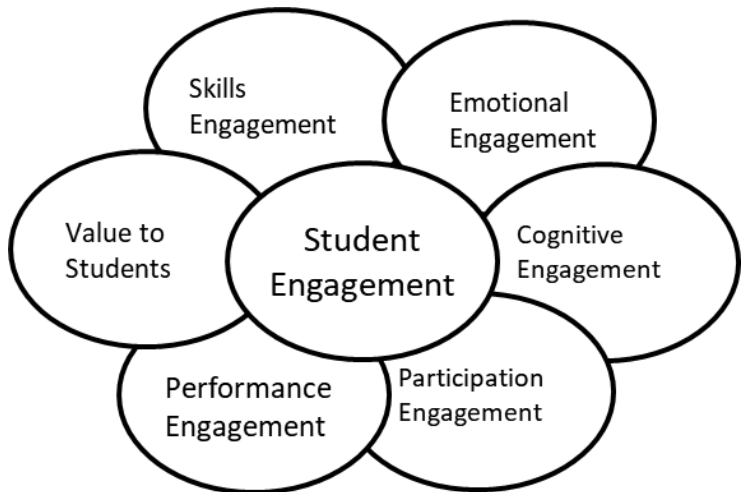

Figure 1. Theoretical dimensions for student engagement

expands Handelsmann et al's work (2005) with an 'Online Student Engagement' Scale. He distributes items across four broad factors, i.e., skills, emotion, participation and performance. Further, Kahu and Nelson (2018) contribute by emphasizing the importance of educational interface facilities in bringing the interaction of institutional factors and student factors to influence student's engagement. Subsequently, they add educational interface to Kahu's (2013) framework. Drawing from the work of Handelsmann et al. (2005), Rich, LePine and Crawford (2010), Burch et al. (2015), Dixson (2015) and literature, we discuss the student engagement across the six different dimensions of skills, emotional, cognitive, participation, performance and value.

\section{Skills Engagement (SE)}

Skills engagement as a construct for student engagement focuses on the efforts put in by student during the course. Astin (1984) points that student engagement must lead to efforts that contribute in achieving the course objectives. Skills engagement refer to making efforts regularly to study, reading the course material, making class notes, organizing the content of course, listening and reading carefully, taking notes, making presentations and attending video sessions (Dixson, 2015). Handelsman et al. (2005) suggest skills engagement as what students "do", and include reading course material, and making efforts to learn. It gets reflected in questions raised in class, receiving of tutor lectures and attendance in supplemental review sessions.

Subsequently, students prefer to earn their degree and thus, engagement tends to hold positive association with time taken to complete the degree. Greater the efforts put in by student in the course, greater would be retention and achievement.

\section{Emotional Engagement}

Emotional engagement refers to the learners' emotions about learning (Marks, 2000). It elaborates with the emotions, interest in class activities and towards peer, course, instructor and learning experience (Fredricks et al., 2004). When students find course interesting and gain the ability to apply it to their own lives (Handelsmann et al., 2005; Dixson, 2015), then they feel more emotionally engaged with the course. Engaging students emotionally brings in more effort, makes the courses more interesting to students and increase the desire to learn (Dixson, 2015). Moreover, the assignment appears to be more engaging and unique to students (Purinton \& Burke, 2019). Positive emotions stimulate learning and enhance cognition, attention and lead to action (Williams et al., 2013); and, instructors can cultivate emotional engagement among students (Black \& Allen, 2018).

\section{Cognitive Engagement}

Cognitive Engagement considers how students approach learning and how their experiences lead to learning (Biggs 1987). It refers to how student interpret their environment and their own selves (Corno \& Mandinach, 1983); integration of student motivation and strategies towards learning course objectives (Richardson \& Newby, 2006). Cognitive engagement indicate behavioral perspective which refer to student's response to 
self-regulation and effective use of deep learning strategies (Fredricks et al., 2004; Park \& Yun, 2017). Further, taking more responsibility for learning (Richardson \& Newby, 2006), extending investment in learning and active participation require cognitive interpretations (Meyer, 2014). Therefore, Cognitive engagement may encourage greater student engagement across all dimensions of learning process.

\section{Participation Engagement}

Students learn when they interact with peers and instructors, i.e., social interaction. According to Handelsman et al. (2005), participation engagement deals with interaction with peers and enjoying the content of the course. Social interaction cultivates social engagement which leads to social construction of knowledge and positively influences the satisfaction level of student (Drouin, 2008). Further, with multi-level interactions, resource sharing and activities involving higher order thinking abilities, student can develop competencies on online learning environments (Oliveira et al., 2011). Dixson (2015) suggests having fun on online chats \& conversations, participating in online forums, helping fellow students, posting regularly in online forums increase the participation engagement. Online courses must develop an environment which encourages building social circle, community and fruitful interactions (Bigatel et al., 2012). Whereas Ragusa and Crampton (2018) point that providing exercises like tick box etc., only distract and detract the students from their academic success rather than engaging them.

\section{Performance Engagement}

Performance engagement points towards the student's efforts in getting good grades and performing well on assignments. Student's desire and goal to achieve success in the course reflects the participation engagement (Dixson, 2015; Handelsman et al., 2005). Participation involves all the suspense, excitement, opportunity of earning grades and being successful in course. Higher levels of participation engagement motivate students to earn good grades (Dixson, 2015; Hofer, 2004; Rocca, 2010). Subsequently, it indicates towards the student's desire to perform well and achieve successful completion of course.

\section{Value to Students}

Purinton and Burke (2019) suggest measurement of perceived value of assignments to students as a dimension of student engagement. Perceived value to students assesses whether the students find the assignments to be unique, unusual and creative enough to bring value to the course. Also, the curriculum design must align the learning outcomes, activities and assessment with Providing value beyond the textbook increases student engagement (Graeff, 2010), as it provides active learning and higher thinking opportunities to students. The student derives value from the engagement in an online course when the course acts as a bridge between the student and study material (Dixson, 2015), engages in higher order thinking skills to apply the concepts in real world problems (Handelsman et al, 2005, Koohang et al, 2016).

\section{METHODOLOGY}

There is lack of consistency among the existing student engagement studies for online learning. Student engagement for online courses has become critical element for universities delivering online education. The study aims to develop a scale for assessing the level of student engagement for online courses for university students.

\section{Questionnaire Design and Measurements}

The study develops a questionnaire which focuses on six constructs collected from literature addressing student engagement (See Table 1). The proposed instrument was reviewed by three experts in the field of education. Six experts in the field of education are requested to review the questionnaire. All experts hold more than ten years of experience in teaching at university level and are suitably qualified (with Ph.D) to review the content of items included questionnaire. For establishing the content validity of the instrument, we calculated content validity indices, i.e., item level content validity index (I-CVI), scale-level content validity index based on average method (S-CVI/Ave) and scale-level content validity index based on universal 
Table 1. Main constructs on which online student engagement is based

\begin{tabular}{|c|c|}
\hline Main constructs & Source \\
\hline Skills Engagement & Astin (1984), Handelsman et al. (2005); Dixson (2015) \\
\hline Efforts Engagement & $\begin{array}{l}\text { Marks (2000), Fredricks et al. (2004), Handelsman et al. (2005), Dixson (2015), Black and } \\
\text { Allen (2018), Purinton and Burke (2019) }\end{array}$ \\
\hline Cognitive Engagement & $\begin{array}{l}\text { Corno and Mandinach (1983), Fredricks et al. (2004), Richardson and Newby (2006), } \\
\text { Meyer (2014), Park and Yun (2017) }\end{array}$ \\
\hline Participation Engagement & $\begin{array}{l}\text { Handelsman et al. (2005), Drouin (2008), Oliveria et al. (2011), Bigatel et al. (2012), } \\
\text { Dixson (2015) }\end{array}$ \\
\hline Performance Engagement & Handelsman et al. (2005), Rocca (2010), Dixson (2015) \\
\hline Value to Students & $\begin{array}{l}\text { Handelsman et al. (2005), Graeff (2010), Dixson (2015), Koohang et al. (2016), Purinton } \\
\text { and Burke (2019) }\end{array}$ \\
\hline
\end{tabular}

Table 2. Content validity indices

\begin{tabular}{|c|c|}
\hline Items & I-CVI \\
\hline$\overline{\lambda 11}$ & 1 \\
\hline$\lambda 12$ & 1 \\
\hline$\lambda 13$ & 1 \\
\hline$\lambda 14$ & 1 \\
\hline$\lambda 15$ & 1 \\
\hline$\lambda 21$ & 1 \\
\hline$\lambda 22$ & 1 \\
\hline$\lambda 23$ & 1 \\
\hline$\lambda 24$ & 1 \\
\hline$\lambda 25$ & 1 \\
\hline$\lambda 26$ & 1 \\
\hline$\lambda 27$ & 0.833 \\
\hline$\lambda 31$ & 1 \\
\hline$\lambda 32$ & 1 \\
\hline$\lambda 33$ & 1 \\
\hline$\lambda 34$ & 1 \\
\hline$\lambda 41$ & 1 \\
\hline$\lambda 42$ & 1 \\
\hline$\lambda 43$ & 1 \\
\hline$\lambda 51$ & 1 \\
\hline$\lambda 52$ & 1 \\
\hline$\lambda 53$ & 1 \\
\hline$\lambda 54$ & 0.8333 \\
\hline$\lambda 61$ & 1 \\
\hline$\lambda 62$ & 1 \\
\hline$\lambda 63$ & 0.8333 \\
\hline$\lambda 64$ & 1 \\
\hline S-CVI/Ave & 0.9815 \\
\hline S-CVI/UA & 0.8889 \\
\hline
\end{tabular}

agreement method (S-CVI/UA) (Polit and Beck, 2006). CVI is a measure to assess the inter-expert agreement and assess the scale The calculated values for the indices are above the threshold value of 0.80 for six experts (Lynn, 1986, Polit \& Beck, 2006; Polit et al., 2007; Yusoff, 2019) (See Table 2). The responses for each item have been collected on 5-point Likert scale (with 1 (strongly disagree) to 5(strongly agree)). A pilot survey with 364 respondents was examined. On the basis of the results of the pilot survey, items with a loading of less than 0.50 are removed from the questionnaire and the revised average variance explained is calculated. Random sampling has been used for the purposes of current study. The participation in the survey is voluntary and the survey was conducted over the period of three months from Jan 2021 to March 2021 . A total number of 1800 questionnaires are circulated. We obtained total 1602 questionnaires valid to be used for further analysis. The inclusion criteria for respondent were that the respondent should have minimum 
Table 3. Participants' information

\begin{tabular}{cc}
\hline Age & $\mathrm{N}(\%)$ \\
\hline $18-20$ & $944(58.9 \%)$ \\
$20-24$ & $658(41.1 \%)$ \\
\hline Previous experience on online courses & $\mathrm{N} \mathrm{( \% )}$ \\
\hline 2 months & $529(33.0 \%)$ \\
2 -6 months & $833(51.9 \%)$ \\
6-12 months & $175(10.9 \%)$ \\
More than 12 months & $65(4.0 \%)$ \\
\hline
\end{tabular}

(Source: author's compilation)

\begin{tabular}{cc}
\hline Gender & $\mathrm{N}(\%)$ \\
\hline Male & $848(52.9 \%)$ \\
Female & $754(47 \%)$ \\
\hline
\end{tabular}

Table 4. Descriptive information of the constructs used in the research model

\begin{tabular}{lcc}
\hline Construct & Mean & Standard Deviation \\
\hline Skills Engagement (SE) & 3.285 & 0.215 \\
Emotional Engagement (EE) & 2.692 & 0.304 \\
Cognitive Engagement (CE) & 3.586 & 0.194 \\
Participation Engagement (PE) & 3.181 & 0.246 \\
Performance Engagement (PeE) & 3.511 & 0.147 \\
Value to Students (VS) & 2.378 & 0.207 \\
Complete Questionnaire & 3.059 & 0.522
\end{tabular}

(Source: author's compilation)

Table 5. Results of parallel anaylsis

\begin{tabular}{lccc}
\hline Component & Adjusted Eigenvalue & Unadjusted Eigenvalue & Estimated Bias \\
\hline 1 & 4.543 & 4.952 & 0.408 \\
2 & 3.261 & 3.610 & 0.349 \\
3 & 2.651 & 2.955 & 0.304 \\
4 & 2.274 & 2.540 & 0.265 \\
5 & 1.854 & 2.085 & 0.231 \\
6 & 1.595 & 1.795 & 0.199 \\
\hline
\end{tabular}

(Source: author's compilation)

two months of experience with online courses. Table 3 presents the demographic information for the survey respondents.

\section{RESULTS}

\section{Descriptive Analysis}

Descriptive statistics of the constructs employed in the research model are summarized and presented in Table 4. The mean values for the constructs obtained through exploratory factor analysis range from 2.378 to 3.586 .

\section{Exploratory Factor Analysis}

To support the factorability on the basis of correlation matrix, the Kaiser-Meyer-Olkin value is found to be 0.834 . The value obtained is well above the acceptable threshold level of 0.60 (Kaiser, 1974). Also, the results for Bartlett's test of sphericity are found satisfactory (Bartlett, 1954) (See Table 6). The results from the Exploratory factor analysis are shown in Table 5. Parallel analysis was employed to discover the number of factors to be retained (Williams et al., 2010). The results obtained from Horn's parallel analysis for component retention are shown in Table 5 and Figure 2 . With adjusted eigenvalues $>1$ (Dinno, 2009) suggests 6 factors to be retained for further analysis Further, the results obtained by applying 'Maximum Likelihood' estimation through 'varimax' rotation, the factor structure explained $57.4 \%$ of the variance. The 
Table 6. KMO test and Bartlett's test results

\begin{tabular}{lc}
\hline Particular & Value \\
\hline Kaiser-Meyer-Olkin Test & 0.834 \\
Bartlett's test of sphericity & \\
$\chi^{2}$ & 7496.244 \\
df & 351.000 \\
p-value & 0.0001 \\
\hline
\end{tabular}

(Source: author's compilation)

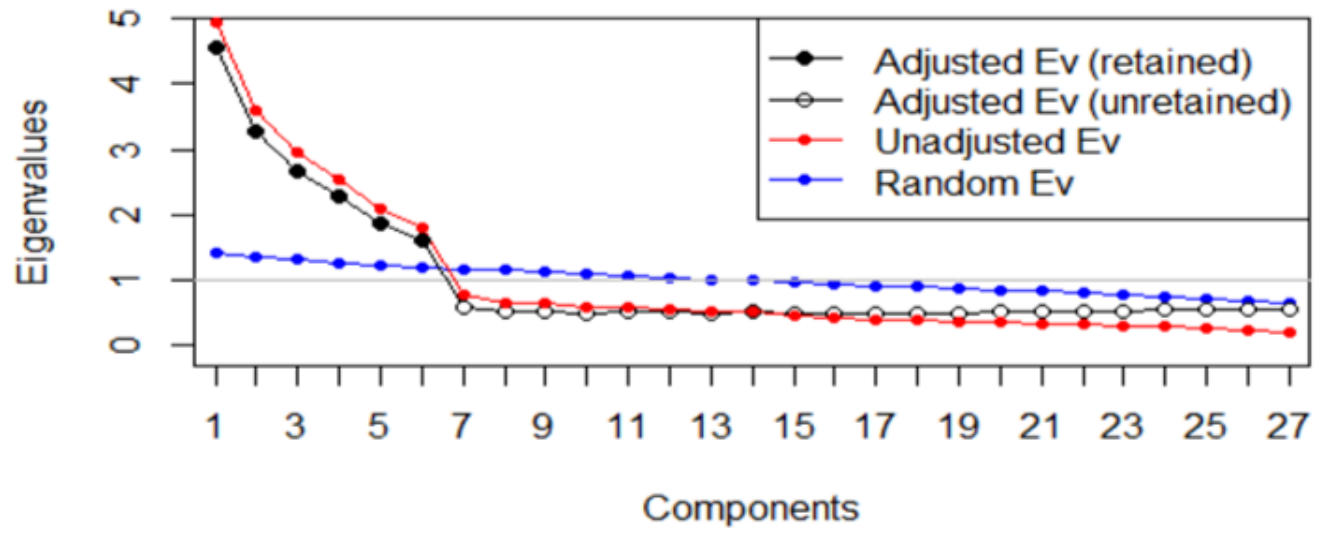

Figure 2. Parallel Analysis

(Source: author's compilation)

communalities for the items in the solution were found to be satisfactory which indicated enough variance captured by components.

Factor loadings for the items range from 0.538 to 0.909 and we found no evidence of cross loadings (See Table 7). So, the initial solution obtained from the exploratory factor analysis show a total of six constructs: Social Engagement (SE) (contains 5 items); Emotional Engagement (EE) (contains 7 items); Cognitive Engagement (CE) (contains 4 items); Performance Engagement (PE) (contains 3 items); Participation Engagement (PeE) (contains 4 items) and Value to Students (VS) (contains 4 items) with 27 error terms (e1 to e27). All the factors suggest satisfactory loadings on the constructs.

Table 7. Results for exploratory factor analysis

\begin{tabular}{lcccc}
\hline Construct & Item label & Item detail & Factor Loading & Communalities \\
\hline Skills & $\lambda 11$ & Feel intensity in working & 0.758 & 0.419 \\
Engagement & $\lambda 12$ & Put in my full efforts & 0.68 & 0.521 \\
(SE) & $\lambda 13$ & Devote efforts and energy & 0.842 & 0.279 \\
& $\lambda 14$ & Give my all to perform & 0.728 & 0.452 \\
& $\lambda 15$ & Work hard to complete the tasks & 0.71 & 0.466 \\
\hline Emotional & $\lambda 21$ & Enthusiasm toward class/ course & 0.657 & 0.53 \\
Engagement & $\lambda 22$ & Feel interested in learning & 0.749 & 0.419 \\
(EE) & $\lambda 23$ & Feel proud on completing tasks, assignments & 0.751 & 0.433 \\
& $\lambda 24$ & Feel excited in attending all session/ Feel energetic & 0.775 & 0.395 \\
& & during class & & 0.782 \\
& $\lambda 25$ & Find assignments and tasks engaging & 0.737 & 0.437 \\
& $\lambda 26$ & Find the course relevant to my life & 0.737 & 0.472 \\
\hline Cognitive & $\lambda 27$ & The way to draw students into the class is effective & 0.716 & 0.591 \\
Engagement & $\lambda 31$ & Feels focused during class & 0.621 & 0.172 \\
(CE) & $\lambda 32$ & Absorbed during class discussion & 0.909 & 0.251 \\
& $\lambda 33$ & Concentrate well during class & 0.863 & 0.478 \\
\hline
\end{tabular}

(Source: author's compilation) 
Table 7 (continued). Results for exploratory factor analysis

\begin{tabular}{lclcc}
\hline Construct & Item label & Item detail & Factor Loading & Communalities \\
\hline Participation & $\lambda 41$ & Get to know my peer & 0.538 & 0.538 \\
Engagement & $\lambda 42$ & Find online chat, discussion with instructor interesting & 0.747 & 0.747 \\
(PE) & $\lambda 43$ & Find online chat, discussion with peers interesting & 0.812 & 0.812 \\
\hline Performance & $\lambda 51$ & Doing well on the tests/quizzes & 0.696 & 0.696 \\
Engagement & $\lambda 52$ & Feel interactions with instructor to be more engaging & 0.791 & 0.791 \\
(PeE) & $\lambda 53$ & Find participation in class activities is satisfactory & 0.629 & 0.629 \\
& $\lambda 54$ & Clarity about the core concepts has been attained & 0.707 & 0.707 \\
\hline Value to & $\lambda 61$ & Exercises given in the class hold value to me & 0.815 & 0.815 \\
Students (VS) & $\lambda 62$ & The process of delivery added value to my course & 0.872 & 0.872 \\
& $\lambda 63$ & The class starts with excitement and interest & 0.652 & 0.652 \\
& $\lambda 64$ & The course had value & 0.756 & 0.756
\end{tabular}

(Source: author's compilation)

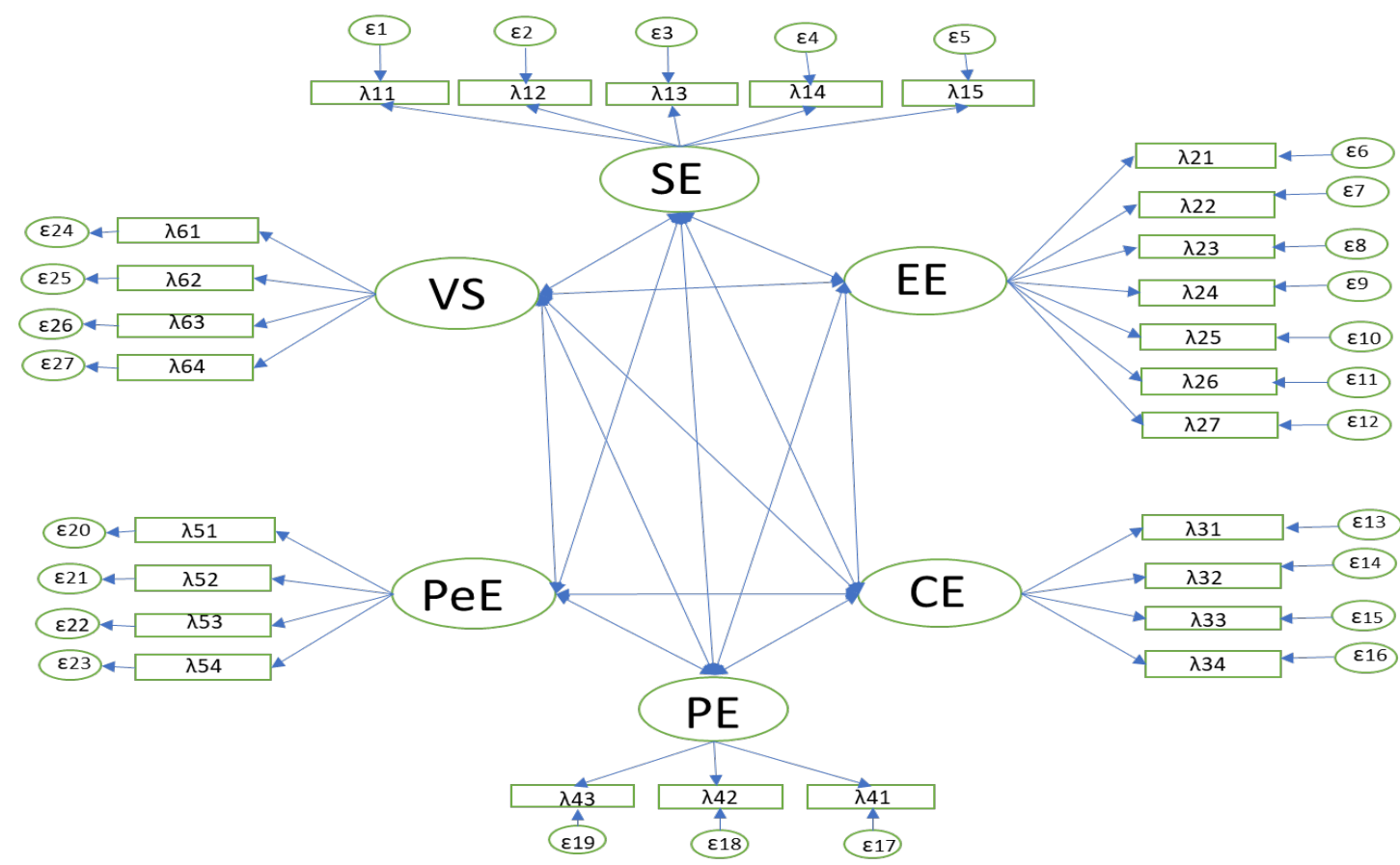

Figure 3. Proposed research model

Table 8. Fit indices

\begin{tabular}{lcc}
\hline Indices & Measurement Model & Recommendation \\
\hline$\chi^{2}(p$ value $)$ & $709.012(0.000)$ & \\
Comparative Fit Index (CFI) & 0.947 & $>0.900$ \\
Tucker-Lewis Index (TLI) & 0.943 & $>0.900$ \\
Goodness of Fit Index (GFI) & 0.917 & $>0.900$ \\
Root mean square error of approximation (RMSEA) & 0.044 & $<0.080$ \\
\hline
\end{tabular}

(Source: author's compilation)

\section{Construct Validity}

Confirmatory factor analysis has been employed to explore the proposed research model (See Figure 3 ) and confirm the scale developed. The fit indices of the research and measurement model were computed. The goodness of fit indices indicates an acceptable fit for the overall model (see Table 8). The values for CFI= $0.947, \mathrm{TLI}=0.943, \mathrm{RFI}=0.899, \mathrm{GFI}=0.917$, and RMSEA $=0.044$. Since measurement model shows adequate fit, then psychometric properties of the model in terms of reliability, convergent validity and discriminant validity are assessed. 
Table 9. Results of discriminant reliability

\begin{tabular}{lcccccc}
\hline Construct & SE & EE & CE & PE & PeE & VS \\
\hline SE & 0.745 & & & & & \\
EE & 0.000 & 0.739 & & & \\
CE & 0.000 & 0.000 & 0.785 & 0.708 & & \\
PE & 0.000 & 0.000 & 0.000 & 0.000 & 0.708 & 0.778 \\
PeE & 0.000 & 0.000 & 0.000 & 0.000 & 0.000 & \\
VS & 0.000 & 0.001 & 0.000 & 0
\end{tabular}

(Source: author's compilation) (where SE=Skills Engagement, EE=Emotional Engagement, $\mathrm{CE}=$ Cognitive Engagement, $\mathrm{PE}=$ Participation Engagement, $\mathrm{PeE}=$ Performance Engagement, VS= Value to Students)

Table 10. Results of internal and convergent reliabilities

\begin{tabular}{|c|c|c|c|c|c|c|}
\hline Factors & Items & Item detail & $\begin{array}{l}\text { Cronbach's } \\
\text { alpha }\end{array}$ & $\begin{array}{l}\text { Factor } \\
\text { loadings }\end{array}$ & $\begin{array}{l}\text { Composite } \\
\text { reliability }\end{array}$ & $\begin{array}{l}\text { Average } \\
\text { variance } \\
\text { extracted }\end{array}$ \\
\hline \multirow[t]{5}{*}{ SE } & $\lambda 11$ & Feel intensity in working & 0.865 & 0.812 & 0.861 & 0.556 \\
\hline & $\lambda 12$ & Put in my full efforts & & 0.756 & & \\
\hline & $\lambda 13$ & Devote efforts and energy & & 0.969 & & \\
\hline & $\lambda 14$ & Give my all to perform & & 0.848 & & \\
\hline & $\lambda 15$ & Work hard to complete the tasks & & 0.791 & & \\
\hline \multirow[t]{7}{*}{$\mathrm{EE}$} & $\lambda 21$ & Enthusiasm toward class/ course & 0.897 & 0.834 & 0.893 & 0.546 \\
\hline & $\lambda 22$ & Feel interested in learning & & 0.941 & & \\
\hline & $\lambda 23$ & Feel proud on completing tasks, assignments & & 0.949 & & \\
\hline & $\lambda 24$ & $\begin{array}{l}\text { Feel excited in attending all session/ Feel energetic during } \\
\text { class }\end{array}$ & & 0.951 & & \\
\hline & $\lambda 25$ & Find assignments and tasks engaging & & 0.965 & & \\
\hline & $\lambda 26$ & Find the course relevant to my life & & 0.944 & & \\
\hline & $\lambda 27$ & The way to draw students into the class is effective & & 0.924 & & \\
\hline \multirow[t]{4}{*}{$\mathrm{CE}$} & $\lambda 31$ & Feels focused during class & 0.854 & 0.66 & 0.863 & 0.617 \\
\hline & $\lambda 32$ & Absorbed during class discussion & & 0.957 & & \\
\hline & $\lambda 33$ & Concentrate well during class & & 0.939 & & \\
\hline & $\lambda 34$ & Devote attention to discussion and activities & & 0.932 & & \\
\hline \multirow[t]{3}{*}{$\overline{P E}$} & $\lambda 41$ & Get to know my peer & 0.796 & 0.585 & 0.746 & 0.502 \\
\hline & $\lambda 42$ & Find online chat, discussion with instructor interesting & & 0.776 & & \\
\hline & $\lambda 43$ & Find online chat, discussion with peers interesting & & 0.821 & & \\
\hline \multirow[t]{4}{*}{ PeE } & $\lambda 51$ & Doing well on the tests/quizzes & 0.811 & 0.766 & 0.799 & 0.501 \\
\hline & $\lambda 52$ & Feel interactions with instructor to be more engaging & & 0.856 & & \\
\hline & $\lambda 53$ & Find participation in class activities is satisfactory & & 0.784 & & \\
\hline & $\lambda 54$ & Clarity about the core concepts has been attained & & 0.827 & & \\
\hline \multirow[t]{4}{*}{ VS } & $\lambda 61$ & Exercises given in the class hold value to me & 0.856 & 0.69 & 0.858 & 0.605 \\
\hline & $\lambda 62$ & The process of delivery added value to my course & & 0.835 & & \\
\hline & $\lambda 63$ & The class starts with excitement and interest & & 0.85 & & \\
\hline & $\lambda 64$ & The course had value & & 0.855 & & \\
\hline
\end{tabular}

(Source: author's compilation) (where $\mathrm{SE}=\mathrm{Skills}$ Engagement, $\mathrm{EE}=\mathrm{Emotional}$ Engagement, $\mathrm{CE}=$ Cognitive Engagement, $\mathrm{PE}=$ Participation Engagement, $\mathrm{PeE}=$ Performance Engagement, $\mathrm{VS}=$ Value to Students)

To successfully obtain results, reliability of the constructs is tested. For reliability, the values for Cronbach's alpha for each construct and the complete questionnaire were calculated. The values for Cronbach's alpha range from 0.796 to 0.897 with a value of cronbach's alpha for overall questionnaire of 0.818 . Referring to Brown (2015); Brown and Moore (2012), we have considered value of more than 0.70 for factor loading to confirm a factor, and 0.50 value for average variance extracted value required. Moreover, each square root degree of the average variance extracted values in one of the specific constructs must be higher than the correlation values between the construct and other constructs for discriminant validity. This indicates sufficient convergent validity supporting the representations of observed variables in the intended latent variable. Referring to Tables $\mathbf{9}$ and $\mathbf{1 0}$ the current study passes a set of reliability tests. 


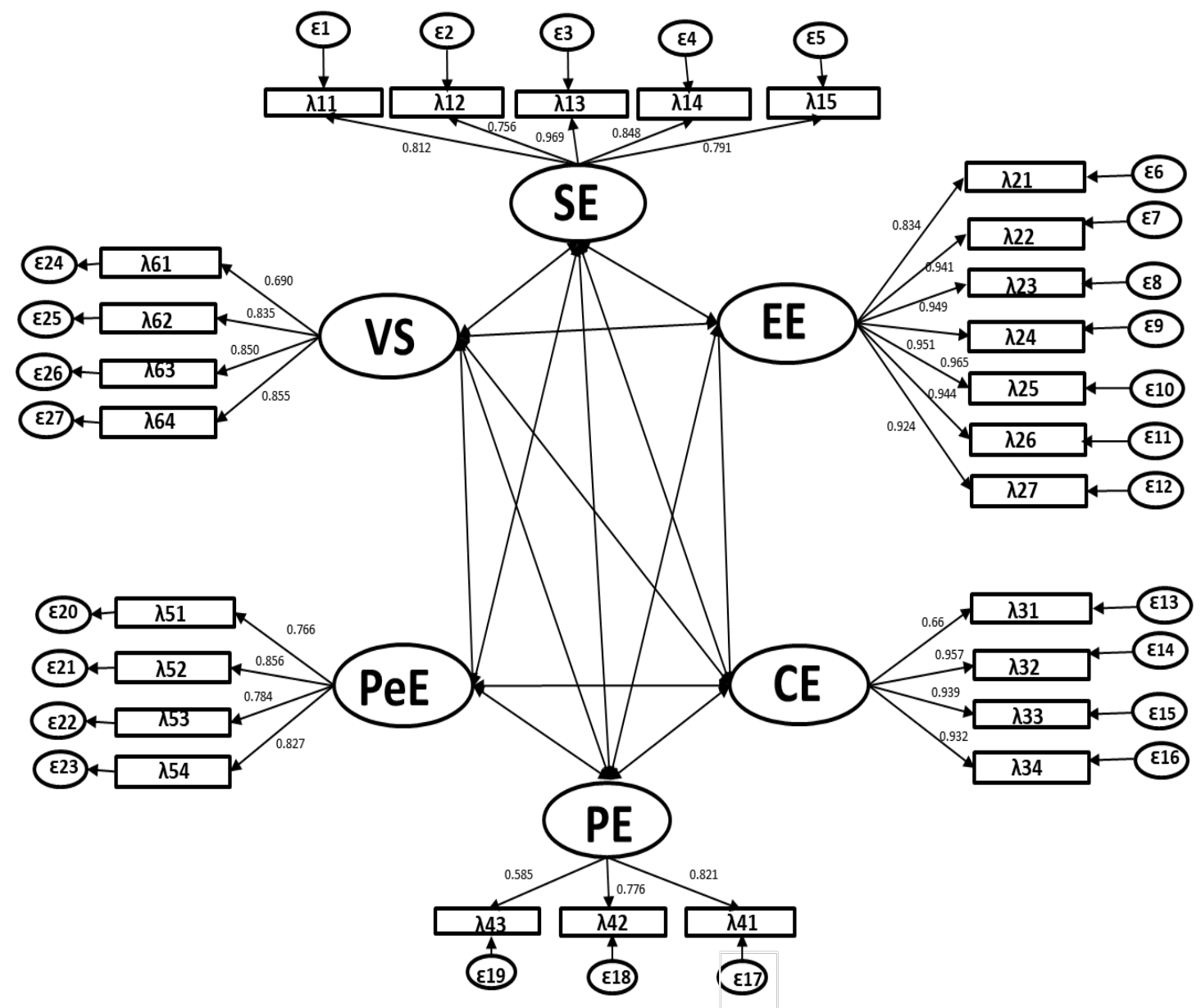

Figure 4. Proposed research model confirmed via confirmatory factor analysis

(Source: author's compilation)

\section{DISCUSSION AND ANALYSIS}

The current study aims to develop a scale for measurement of student engagement for online courses. The results indicate that there are six main constructs that play a significant role which influence student engagement on online courses. The results of the study are consistent with existing literature in student engagement in online platforms (Dixson, 2015; Fredrick et al, 2004; Park \& Yun, 2017, Purinton \& Burke, 2019).

Furthermore, this study finds the skills engagement, emotional engagement, cognitive engagement, performance engagement but found participation engagement and value to students to be challenging.

Skills engagement marks on the constructivist assumption of how students are willing to make best use of their personal resources like time and efforts to complete the study material (Dixson, 2015; Handelsman et al., 2005; Purinton \& Burke, 2019) acquire the high-quality learning.

Emotional engagement, as a significant construct for student engagement for online courses, focuses on to cultivate connect with learning experience via class activities, peer group connections (Black \& Allen, 2018; Purinton \& Burke, 2019). If a student feels emotionally connected with the learning experience, then he would attempt to put his best foot forward to achieve best possible results and complete all the assignments as per the time line of the courses. It enhances the application aspect of the learning acquired during the course. Getting students emotionally engaged during online courses can become challenging, yet it has been given sufficient importance for engaging students on online courses. 
In line with Park and Yun (2017), and Fredrick et al. (2004), cognitive engagement reflects on the capacity of the student response towards learning activities. For example, online discussion boards help weak students to build in cognitive capacity by discussion with strong ones and by applying peer questions. It can be improved by adopting wide range of strategies for learning so that students relate with the subject easily. Participation engagement becomes more challenging on online student engagement as interactions between peers and instructors gets limited. Yet, including collaborative exercises in the course structure can help instructors to make course more participative and improve the overall student engagement (Kurucay \& Innan, 2017).

Performance engagement, as a construct, diverts the attention of students towards the achievement of goals of the learning experience (Dixson, 2015; Hofer, 2004). Bringing in the lens on graduate students, students attempt to perform better on their quizzes, assignments. Performing and acquiring good grades marks the engagement of students in the learning and knowledge acquisition process. Strong relationship between communication with instructors improves satisfaction from online courses and engages students as well (Cole, 2016). Additionally, value to students, as a construct, brings the attention of students towards the achievement of learning outcomes and feeling more engaged via value driven from achievement (Graeff, 2010). Bringing in value to students provide ample grounds for students to carry out future research in order to develop supplementary knowledge on this (Hayes, 2018).

The results of the study are consistent with existing literature in student engagement in online platforms (Dixson, 2015; Fredrick et al, 2004; Park \& Yun, 2017; Purinton \& Burke, 2019).

\section{IMPLICATIONS}

The present study tries to make following implications to the existing literature on student engagement. Considering an academic perspective, the study affirms the effectiveness and efficiency for online courses in engaging students. The study decomposes student engagement into six constructs indicating different dimensions of student engagement. Applying an academic and contextual lens, the study suggests how meaningful learning experiences can be achieved for online courses. The theoretical overlapping of different dimensions of student engagement influences the engagement level of student in an online class.

From an institution's perspective, the findings suggest that the research model can be extended to allow higher education institutions to institute their own set of guidelines and embedded the dimensions of student engagement in the design, structure, and delivery of the online courses. Measuring on the student engagement would help the institutions in development and transformation of knowledge that help in building and sustaining a better community.

\section{LIMITATIONS AND SCOPE FOR FUTURE}

The study has few limitations. First, the study has been carried out to university students who are either pursuing their graduation or post-graduation. Second, the research model can be extended to include set of demographics. Thus, future research should utilize the results and implications of the research model presented in the current study for addressing the student engagement under different cultural conditions and different disciplines.

Funding: The author received no financial support for the research and/or authorship of this article.

Declaration of interest: Author declares no competing interest.

Data availability: Data generated or analysed during this study are available from the author on request.

\section{REFERENCES}

Astin, A. W. (1984). Student involvement: A developmental theory for higher education. Journal of college student personnel, 25(4), 297-308. 
Axelson, R. D., \& Flick, A. (2010). Defining student engagement. Change: The magazine of higher learning, 43(1), 38-43. https://doi.org/10.1080/00091383.2011.533096

Bigatel, P. M., Ragan, L. C., Kennan, S., May, J., \& Redmond, B. F. (2012). The identification of competencies for online teaching success. Journal of Asynchronous Learning Networks, 16(1), 59-77. https://doi.org/10.24059/olj.v16i1.215

Biggs, J. B. (1987). Student approaches to learning and studying. Research monograph. Australian Council for Educational Research Ltd.

Black, S., \& Allen, J. D. (2018). Part 4: Academic self-concept and emotions. The Reference Librarian, 59(1), 42-55. https://doi.org/10.1080/02763877.2017.1349022

Brown, T. A. (2015). Confirmatory factor analysis for applied research. Guilford publications.

Brown, T. A., \& Moore, M. T. (2012). Confirmatory factor analysis. In R. H. Hoyle (Ed.), Handbook of structural equation modeling (pp. 361-379). The Guilford Press.

Bryson, C. (2014). Clarifying the concept of student engagement. In C. Bryson (Ed.), Understanding and developing student engagement (pp. 21-42). Routledge. https://doi.org/10.4324/9781315813691

Bryson, C., Cooper, G., \& Hardy, C. (2010). Reaching a common understanding of the meaning of student engagement [Paper presentation]. Society of Research into Higher Education Conference, Celtic Manor, Wales, 14-16, December 2010.

Burch, G. F., Heller, N. A., Burch, J. J., Freed, R., \& Steed, S. A. (2015). Student engagement: Developing a conceptual framework and survey instrument. Journal of Education for Business, 90(4), 224-229. https://doi.org/10.1080/08832323.2015.1019821

Chalmers, D. (2008). Indicators of university teaching and learning quality. Australian Learning \& Teaching Council.

Cole, A. W. (2016). Testing the impact of student preference for face-to-face communication on online course satisfaction. Western Journal of Communication, 80(5), 619-637. https://doi.org/10.1080/10570314.2016.1186824

Corno, L., \& Mandinach, E. B. (1983). The role of cognitive engagement in classroom learning and motivation. Educational Psychologist, 18(2), 88-108. https://doi.org/10.1080/00461528309529266

Dinno, A. (2009). Implementing Horn's parallel analysis for principal component analysis and factor analysis. The Stata Journal, 9(2), 291-298. https://doi.org/10.1177/1536867X0900900207

Dixson, M. D. (2015). Measuring student engagement in the online course: The Online Student Engagement scale (OSE). Online Learning, 19(4), n4. https://doi.org/10.24059/olj.v19i4.561

Drouin, M. A. (2008). The relationship between student's perceived sense of community and satisfaction, achievement, and retention in an online course. Quarterly Review of Distance Education, 9(3).

Fredricks, J. A., Blumenfeld, P. C., \& Paris, A. H. (2004). School engagement: Potential of the concept, state of the evidence. Review of Educational Research, 74(1), 59-109. https://doi.org/10.3102/00346543074001059

Graeff, T. R. (2010). Strategic teaching for active learning. Marketing Education Review, 20(3), 265-278. https://doi.org/10.2753/MER1052-8008200307

Handelsman, M. M., Briggs, W. L., Sullivan, N., \& Towler, A. (2005). A measure of college student course engagement. The Journal of Educational Research, 98(3), 184-192. https://doi.org/10.3200/JOER.98.3.184-192

Hatch, D. K. (2012). Unpacking the black box of student engagement: The need for programmatic investigation of high impact practices. Community College Journal of Research and Practice, 36(11), 903-915. https://doi.org/10.1080/10668926.2012.690319 
Hayes, A. F. (2018). Introduction to mediation, moderation, and conditional process analysis: A regressionbased approach. Guilford publications.

Hofer, B. K. (2004). Exploring the dimensions of personal epistemology in differing classroom contexts: Student interpretations during the first year of college. Contemporary educational psychology, 29(2), 129-163. https://doi.org/10.1016/j.cedpsych.2004.01.002

Jennings, J. M., \& Angelo, T. A. (2006). Student engagement: Measuring and enhancing engagement with learning [Paper presentation]. Proceedings of a Symposium, Frederic Wallis House Conference Centre, Lower Hutt, Wellington.

Kahn, W. A. (1990). Psychological conditions of personal engagement and disengagement at work. Academy of Management Journal, 33(4), 692-724. https://doi.org/10.5465/256287

Kahu, E. R. (2013). Framing student engagement in higher education. Studies in Higher Education, 38(5), 758773. https://doi.org/10.1080/03075079.2011.598505

Kahu, E. R., \& Nelson, K. (2018). Student engagement in the educational interface: understanding the mechanisms of student success. Higher Education Research \& Development, 37(1), 58-71. https://doi.org/10.1080/07294360.2017.1344197

Kehrwald, B. (2008). Understanding social presence in text-based online learning environments. Distance Education, 29(1), 89-106. https://doi.org/10.1080/01587910802004860

Koohang, A., Paliszkiewicz, J., Klein, D., \& Nord, J. H. (2016). The importance of active learning elements in the design of online courses. Online Journal of Applied Knowledge Management, 4, 17-28. https://doi.org/10.36965/OJAKM.2016.4(2)17-28

Kuh, G. D. (2003). What we're learning about student engagement from NSSE: Benchmarks for effective educational practices. Change: The Magazine of Higher Learning, 35(2), 24-32. https://doi.org/10.1080/00091380309604090

Kuh, G. D., Cruce, T., Shoup, R., Kinzie, J., \& Gonyea, R. M. (2007). Unmasking the effects of student engagement on college grades and persistence. American Educational Research Association Annual Meeting. https://doi.org/10.1080/00221546.2008.11772116

Kurucay, M., \& Inan, F. A. (2017). Examining the effects of learner-learner interactions on satisfaction and learning in an online undergraduate course. Computers \& Education, 115, 20-37. https://doi.org/10.1016/j.compedu.2017.06.010

Leach, L. (2016). Enhancing student engagement in one institution. Journal of Further and Higher Education, 40(1), 23-47. https://doi.org/10.1080/0309877X.2013.869565

Lynn, M. R. (1986). Determination and Quantification of content validity. Nursing Research, 35(6), 382-385. https://doi.org/10.1097/00006199-198611000-00017

Marks, H. M. (2000). Student engagement in instructional activity: Patterns in the elementary, middle, and high school years. American Educational Research Journal, 37(1), 153-184. https://doi.org/10.3102/00028312037001153

Meyer, K. A. (Ed.). (2014). Student engagement online learning: What works and why. ASHE higher education report, 40(6), 1-114. https://doi.org/10.1002/aehe.20018

Newmann, F. M. (1992). Student engagement and achievement in American secondary schools. Teachers College Press.

Nystrand, M., \& Gamoran, A. (1991). Instructional discourse, student engagement, and literature achievement. In Research in the Teaching of English (pp. 261-290).

Oliveira, I., Tinoca, L., \& Pereira, A. (2011). Online group work patterns: How to promote a successful $\begin{array}{lllll}\text { collaboration. Computers \& } \quad \& \quad \text { Education, } & \text { 1348-1357. }\end{array}$ https://doi.org/10.1016/j.compedu.2011.01.017 
Pace, C. R. (1980). Measuring the quality of student effort. Current Issues in Higher Education, 2(1), 10-16.

Park, S., \& Yun, H. (2017). Relationships between motivational strategies and cognitive learning in distance $\begin{array}{lllll}\text { education } \quad \text { courses. } & \text { Bistance 302-320. }\end{array}$ https://doi.org/10.1080/01587919.2017.1369007

Pascarella, E. T., Seifert, T. A., \& Blaich, C. (2010). How effective are the NSSE benchmarks in predicting important educational outcomes?. Change: The Magazine of Higher Learning, 42(1), 16-22. https://doi.org/10.1080/00091380903449060

Polit, D. F., \& Beck, C. T. (2006). The content validity index: Are you sure you know what's being reported? Critique and Recommendations. Research in Nursing \& Healh, 29(5), 489-497. https://doi.org/10.1002/nur.20147

Polit, D. F., Beck, C. T., \& Owen, S. V. (2007). Is the CVI an acceptable indicator of content validity? Appraisal and recommendations. Research in Nursing \& Health, 30(4), 459-467. https://doi.org/10.1002/nur.20199

Purinton, E. F., \& Burke, M. M. (2019). Student Engagement and Fun: Evidence from the Field. Business Education Innovation Journal, 11(2).

Radloff, A., \& Coates, H. (2010). Doing More for Learning: Enhancing Engagement and Outcomes: Australasian Survey of Student Engagement: Australasian Student Engagement Report. Australian Council for Educational Research (ACER).

Ragusa, A. T., \& Crampton, A. (2018). Sense of connection, identity and academic success in distance education: Sociologically exploring online learning environments. Rural Society, 27(2), 125-142. https://doi.org/10.1080/10371656.2018.1472914

Rich, B. L., Lepine, J. A., \& Crawford, E. R. (2010). Job engagement: Antecedents and effects on job performance. Academy of Management Journal, 53(3), 617-635. https://doi.org/10.5465/amj.2010.51468988

Richardson, J. C., \& Newby, T. (2006). The role of students' cognitive engagement in online learning. American Journal of Distance Education, 20(1), 23-37. https://doi.org/10.1207/s15389286ajde2001_3

Rocca, K. A. (2010). Student participation in the college classroom: An extended multidisciplinary literature review. Communication Education, 59(2), 185-213. https://doi.org/10.1080/03634520410001682447

Tinto, V. (2014). Tinto's South Africa lectures. Journal of Student Affairs in Africa, 2(2), 5-28. https://doi.org/10.14426/jsaa.v2i2.66

Trowler, V., \& Trowler, P. (2010). Student engagement evidence summary. The Higher Education Academy.

Williams, K. H., Childers, C., \& Kemp, E. (2013). Stimulating and enhancing student learning through positive emotions. Journal of Teaching in Travel \& Tourism, 13(3), 209-227. https://doi.org/10.1080/15313220.2013.813320

Yusoff, M. S. B. (2019). ABC of content validation and content validity index calculation. Resource, 11(2), 4954. https://doi.org/10.21315/eimj2019.11.2.6

Correspondence: First Author, Assistant Professor, Affiliation of First Author, Turkey 